\title{
ENGLISH LANGUAGE EDUCATION IN EARLY CHILDHOOD THROUGH THE CHILDREN'S SONGS
}

\author{
Si Luh Nyoman Seriadi \\ IHDN Denpasar
}

\begin{abstract}
The development of the global world has demanded the children of today to grow faster and compete more closely. One ability they should have to be able to compete with the globalization is ability to communicate in English. As we know that the ability of children to absorb a variety of information around it is extraordinary. So, when we want a child can have a good ability in communicating with English, English learning should be done since the early phase. But in practice, there are some obstacles encountered such as the children difficulty in understanding the subjects of this foreign language. This is reasonable because the position of English in Indonesia is as a foreign language. To overcome these obstacles, it requires effective learning techniques, appropriate, and interesting so that learners are motivated to learn this foreign language. To create a fun English classroom atmosphere, one of them is with the use of songs for learning media.
\end{abstract}

Keywords: English Education, Early Childhood, Songs

\section{Introduction}

The development of the global world has demanded the children of today to grow faster and compete more closely. One indicator to achieve success is the ability to communicate. Not only communicate with his own mother tongue, but also proficient in communicating with English. Therefore, English learning becomes an important thing to give to children.

As we know that the ability of children to absorb a variety of information around it is extraordinary. Early childhood at this time is like a sponge. The sponge will absorb the surrounding water. In this metaphor, water is everything the child receives and which is then processed as information. So when we want a child can have a good ability in communicating with English, English learning should be done since the early phase. It is then that bolted some schools of primary or elementary school or enter English as one of the subjects given to their students.

But in practice, there are some obstacles encountered such as the children difficulty in understanding the subjects of this foreign language. This is reasonable because the position of English in Indonesia is as a foreign language. Understanding a 
foreign language is a language that is not used to communicate daily but is actively used in the classroom only when the process of learning and teaching takes place. This is in accordance with the statement of the researcher who states about the understanding of a foreign language is a language that is not used as a communication tool in a particular country where the language is taught (Miranti, Engliana, dan Hapsari, 2015: 167).

To overcome these obstacles, it requires effective learning techniques, appropriate, and interesting so that learners are motivated to learn this foreign language. Effective learning is a learning that allows learners to learn easily, fun, and achievable learning objectives are set (HR, 2015: 6). For that, teachers are required to create an unusual learning atmosphere. In other words, the learning process is not just interpreted as the teacher teaches a material to the students while the students listen to the explanation from the teacher but a teacher must create a lively learning environment (active learners follow teaching and learning activities with a fun situation). To create a fun English classroom atmosphere, one of them is with the use of songs for learning media.

\section{DISCUSSION}

\subsection{Early Childhood Education and}

\section{English Language}

Early childhood is defined as the period from birth to eight years old. A time of remarkable brain growth, these years laid the foundation for subsequent learning and development. Early childhood education is frequently applied to the education of young children from birth through eight or the type of education which takes place before formal education either at home, neighbor, child care centers, preschool or nursery school, Montessori and other pre-primary schools (EFA, Global Monitoring Report 2007). Quality Early Childhood Education (ECCE) helps a child develop their potential and promotes their social, emotional, physical and cognitive development. (UNESCO 2012). Early childhood is a crucial time period for the development of children's mental functions. This development, including the emergence of language, motor skills, psychosocial, cognitive, and learning abilities, is now known to be greatly influenced by exogenous factors, including the educational environment to which a child is exposed during the first 6 to 8 years of life (Bowman, 2001).

It has been realized that Early Childhood Care and Education (ECE or ECCE) can be a major input into a 
child's formal education. A number of studies links ECE to increases in school readiness for primary school, and it has been shown that school readiness is an important predictor of early school achievement (ForgetDubois et al 2007). One review of 36 studies of ECE effectiveness in

Small-scale demonstration and large-scale public programs-each study comparing participants with a control group of non-participants finds "overwhelming evidence that ECCE can produce great improvements in school success." (Barnett 1995, pg. 40) Children who attend well-planned, high-quality ECE programs in which the curriculum aims are specified and integrated across domains tend to learn more and are better prepared to master the complex demands of formal schooling." (Bowman 2001, p. 7-8).

English has become an international language used almost in all areas of global life. English has also become the world's language that dominates the era of communication to connect and transfer science to the world. This gives the assumption that the mastery of English is a very important requirement for modern society today because the mastery of English makes it easier for someone to expand their interaction in the international world. As Fromkin has said, "English has been called 'the lingua franca of the world"' (1990: 259).

In fact, mastery of English is a skill that is very important in the era of information and communication today. This really determines how we can interact globally. The current issue of globalization demands quality human resources and is able to communicate in various foreign languages, especially English as an international language. This foreign language skills are required to master the science, have a wide range of relationships and a good career. This makes everyone from all walks of life motivated to speak English.

The tendency of people to master the foreign language, making them competing to include their children to learn English as one of the skills developed. This is based on the assumption that children learn foreign languages faster than adults (Santrock, 2007: 313). A study by Johnson and Newport, 1991 (Santrock, 2007: 313) showed that immigrants from China and Korea who began living in America at the age of 3 to 7 years of English ability is better than older children or adults.

Children in early childhood are on their preoperational stage. So, if early childhood learn English they are in pre-operational stage and therefore they need lots of illustrations, models, 
pictures, and other activities. Apparently Piaget lacks the belief that the use of direct learning is just as important in the development of natural knowledge, logic, and mathematics (Wood, 2001). Currently, many studies are proving and quite convincing that the actual benefits of verbal learning, social interaction, and culture can improve learning optimally. This is evident in the Zone of Proximal Development (ZPD) theory developed by Vygotsky (1986). What is ZPD?

"ZPD is the distance between the actual development level as determined by independent problem solving and the level of potential development as determined through problem solving under adult guidance or in collaboration with more capable peers"

If a child cannot understand something, then according to Piaget the child is not mentally ready. For Vygotsky, the lesson is beyond the area of knowledge development. In this case, the lesson has a social value, for the learning of English this social interaction can be done in the form of pair or group duty.

\subsection{English Lesson through Songs}

For the education system, English language learners are learners in provincially funded English language schools whose first language is a language other than English

(www.uio.no/studier/emner/hf/ikos/ EXFACO). In education therefore, language is the vehicle by which knowledge is jointly constructed, internalize and exchange verbal or symbolic utterances for communication (Mercer,1994). Thus, the present study is concern on examining the learning through English language in early childhood education particularly in English medium schools, these schools are the schools which use English language to teach academic subjects in countries where first language (LI) of the majority population is not English. The study particularly explores factors which influence parents sending their children in those schools and identifying the associated challenges for sending children in English medium schools.

In essence, according to Curtain and Pesola (1994) children will learn a foreign language well if the learning process occurs in a context that is communicative and meaningful to them. For children this context includes social situations, cultural, games, singing, fairy tales 
and artistic, craft, and sports experiences.

Two important theories about the development of this psychology, namely the theory Piaget and Vygotsky can provide important information how we think of children as students / learners of language, especially foreign languages. According to Piaget, children are active learners and thinkers. They always interact continuously with the world environment and solve the problems they face in the environment, so that the learning process occurs actively. This is produced by the child alone, not from the results of imitating others and obtained from birth. Donaldson (1998) emphasizes Piaget's implication that children are always trying to actively seek understanding of the world, asking and wanting to know. Also since childhood the child always has a meaning and purpose; he wants to ask or do something.

Opinion Vygotsky (1986) is different from Piaget on language and other people in the world of children. He argues that children are part of the social. Center for child development and learning occurs in a social context in the world are filled with people, dealing with children from birth. People play an important role to help children learn (playing, reading stories, talking, showing things, ideas). Here adults are the world's mediators for children. Ability to learn through instruction and media is a characteristic of human intelligence. With the help of adults / teachers the child can do and understand more than they do on their own. This also means learning to do something and learning to think that both are helped by interaction with adults. Many of Vygotsky's ideas are used to construct a foreign language teaching framework for children.

The most sensitive period of language in a person's life is between the ages of two and seven. All aspects of language should be introduced to the child before this sensitive period ends. In this sensitive period it is very important to introduce a good and correct way of speaking, as it is very useful for communicating with the environment (Maria Montessori, 1991). Based on the theory, it is appropriate if English is introduced to the child as early as possible. Given English is the first foreign language in Indonesia, then the learning process should be done in stages. The selection of materials appropriate to the age of the child and also effective for the child's cognitive language development as well as the pleasant learning situation should be a major concern in the success of a learning process. 


\subsection{Song Selection}

Songs can be used as learning materials in the course or in a group. Everyone loves songs or music. Often when someone likes something, it is easy to learn through the pleasure.

But how do I make course participants or children learn through songs? Below are tips that can be used.

1. Students hear the song several times in the class, then invite students to sing the song. So together learn about the song.

2. The song continues to be sung until the song is memorized by all the students in the class.

3. When students are able to follow the rhythm of the song and enjoy with the music and lyrics, next is to give the song script to the student's partner.

So two people get one song script.

4. In the script there is a song lyrics whose words are lost, a student will be required to complete the words.

5. Students can guess the word, and interpret the word.

Through the song make it easier for students to remember the vocabulary, in addition of course to improve students' self confidence in speaking English. And the learned skill is to train students' listening skills (www.ef.co.id).
Some things that must be considered in the learning process through the song, namely:

- Songs contain words that are easy to memorize.

- Songs with simple words will easily memorize the words. Can try Big Big World song because the song is so memorable because the lyrics are repetitive and short. Songs with long lyrics or complicated vocabulary, will present difficulties when students want to remember it.

- Familiarize students singing without looking at the lyrics.

- When it is fluent to sing the song, encourage students not to look at text or lyrics anymore. They will memorize, regardless of the lyrics and rely solely on hearing and mere memorization.

English language learning, especially in early childhood, more emphasis on the knowledge of the basic commands (Basic Instructions) and knowledge of the names of objects, or objects that are around them (Vocabulary). Various types of songs can be used to suit our needs in the classroom. Songs can be categorized into activity song, animal song, counting song, food song, learning song, and so on. As an introduction to learning a teaching 
material, teachers can use the song as its apperception. Example: When teaching with the theme of my face, teachers can invite children to sing, among others: the song "My Face" "My Eyes, my ears, my nose, my mouth, 2x"

Similarly, when teaching other teaching themes, such as the theme of recognizing fruits can also use songs such as:

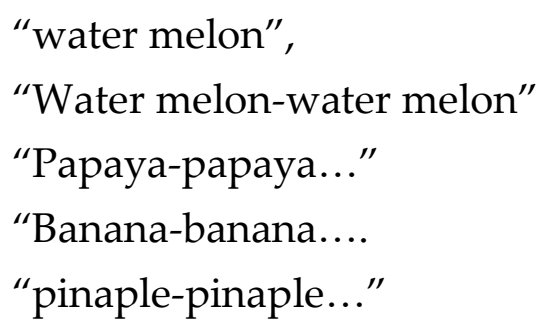

When children sing the song, the teacher can he showed the card or the image in question. So hopefully the child can understand the shape or picture of fruits visually and pronounce the sound well and correctly. Can also directly involve the children by holding a picture of each fruit and pointing the fruit in question alternately. Another example can be sought from a variety of sources that already exist, or have been created by the teachers themselves to consider the suitability of the circumstances and the material to be delivered.

Here are examples of songs that can be used in English classes are:

1. Song Title: "If you're happy and you know it
Lyric: If you're happy and you know it

Clap your hands

If you're happy and you know it

Clap your hands

If you're happy and you know it

Then your face will surely show it

If you're happy and you know it

Clap your hands. Clap clap

If you're happy and you know it

Stomp your feet (stomp stomp)

If you're happy and you know it

Stomp your feet (stomp stomp)

If you're happy and you know it

Then your face will surely show it

If you're happy and you know it

Stomp your feet (stomp stomp)

If you're happy and you know it,

Shout "Hurray!" (hoo-ray!)

If you're happy and you know it,

Shout "Hurray!" (hoo-ray!) 
If you're happy and you know it,

Then your face will surely show it,

If you're happy and you know it,

Shout "Hurray!" (hoo-ray!)

If you're happy and you know it, do

All three (clap-clap, stompstomp, hoo-ray!)

If you're happy and you know it, do

All three (clap-clap, stompstomp, hoo-ray!)

If you're happy and you know it,

Then your face will surely show it

If you're happy and you know it, do

All three. (clap-clap, stompstomp, hoo-ray!)

The goal: Physical movement, channeling excessive student energy, training memory, coordination and concentration, developing vocabulary, grammar, bringing a joyful atmosphere.

2. Song Tittle: 10 little Indians

Lyric : 1 little 2 little 3 little Indians

4 little 5 little 6 little Indians

7 little 8 little 9 little Indians

10 little Indian boys

10 little 9 little 8 little Indians

7 little 6 little 5 little Indians
4 little 3 little 2 little Indians

1 little Indians boy

Objective: Strengthening the concept of numbers, arithmetic (plus, minus), trains memory, concentration, coordination, vocabulary, grammar, practicing hand movements.

3. Song Tittle: Head, Shoulders, Knees and Toes

Lyric: Head shoulders knees and toes

Knees and toes

Knees and toes

Head shoulders knees and toes

Eyes ears mouth nose

Objective: Learn the names of the members of the body, physical movement, channeling excess energy students, train memory, coordination and concentration, develop vocabulary, grammar and presents a jovial mood

Beside the song examples above, there still so many songs that can be used as a tools in teaching English language for children.

\section{CONCLUSION}

The development of the global world has demanded the children of today to grow faster and compete more closely. One ability they should have to be able to compete with the globalization is ability to communicate in English. But in practice, there are some obstacles 
encountered such as the children difficulty in understanding the subjects of this foreign language. To overcome these obstacles, it requires effective learning techniques, appropriate, and interesting so that learners are motivated to learn this foreign language. Effective learning is a learning that allows learners to learn easily, fun, and achievable learning objectives are set. English language learning, especially in early childhood, more emphasis on the knowledge of the basic commands (Basic Instructions) and knowledge of the names of objects, or objects that are around them (Vocabulary). Various types of songs can be used to suit our needs in the classroom. Songs can be categorized into activity song, animal song, counting song, food song, learning song, and so on.

\section{REFERENCES}

Barnett, W. 1995. Long-Term Effects of Early Childhood Programs on Cognitive and School Outcomes, The Future of Children, 5:3, 2550

Bowman, B., M Donovan and M. Burns, eds. 2001. Eager to Learn: Educating Our Preschoolers, Committee on Early Childhood Pedagogy, Commission on Behavioral and Social Sciences and Education,National Research Council, National Academy Press, Washington, DC.

Brown, D. 2000. Teching by Principles. Cameron, L. 2001. Teaching Languages to Young Lerner. Cambridge: CUP.

Curtain, Helena and Pesola, Carol A.B. (1994). Language and Children. New York : Longman Publishing Group

Donaldson, Orlich. (1998). Teaching Strategies. Boston : Houghton Miffin Company.

Educational Practice Ed. Stierer B \& Maybin J Clevedon: Multilingual Matters MOE. (2001).Guidelines for Promoting English Langauge Instruction in Primary Schools. Ministry of Education. Beijing: Ministry of Education.

Forget-Dubois, N., J. at al. (2007). "Predicting Early School 
Achievement With the EDI: A Longitudinal PopulationBased Study" Early Education and Development. 18:3, 405-426

HR, Mansyur. 2015. Menciptakan Pembelajaran Efektif Melalui Apersepsi. Jurnal E-Buletin, Februari 2015, 2355-3189.

https://www.ef.co.id/englishfirst/engl ishstudy/bahasa-inggris/tipspembelajaran-bahasa-inggrismelalui-lagu.aspx

Khairini, Ade Irma. 2011. Pendidikan Bahasa Inggris Untuk Anak Usia Dini. Diakses dari http://digilib.unimed.ac.id/448 /1/Fulltext.pdf.

Mercer N (1994) Neo-Vygotskyan theory and classroom education. In Language,Literacy and Learning in

Miranti, Ira, Engliana, dan Hapsari, Fitri Senny. 2015. Penggunaan Media Lagu Anak-Anak dalam Mengembangkan Kemampuan Kosakata Bahasa Inggris Siswa di Paud. Jurnal Ilmiah Kependidikan, Vol. II, No 2: 167-173.

Montessori, Dr. Maria. (1991). The discovery of the Child. New York: Ballatine Books

Mwalongo, Leopard Jacob. 2016. Learning through English Language in Early Childhood Education: A Case of English
Medium Schools in China. Journal of Education and Practice. Vol.7/28 2016. Diakses dari

https://files.eric.ed.gov/fulltext /EJ1118594.pdf

Santrock, John W (2007) Child Development, Taxas: McGrawHill

Sophya, Ida Vera. 2013. Pembelajaran Bahasa Inggris Melalui lagu pada Anak Usia Dini. ThufuLA. Vol. 1/ 1 JuliDesember 2013.

UNESCO. (2012). EFA global monitoring report 2007: Strong foundations: Early childhood care and education, UNESCO

Vygotsky, L.S. (1986). Thought and Language. Cambridge, M.A. : The MIT Press

Wood, Karlyn E. (2001). Interdisciplinary Instruction. www.uio.no/studier/emner/hf/ikos/E XFACO 